\title{
Spring in the Qu'Appelle Valley
}

by Robert W. Storer, Museum of Zoology, University of Michigan, Ann Arbor

Sunk in a seemingly endless expanse of prairie and aspen parkland, the Qu'Appelle Valley always comes as a surprise. Even the approaches are unexpected, the roads dipping abruptly from the prairie and winding through wooded side coulees which open out onto the mile-wide glacial valley. The 500-foot walls of the valley are moulded into soft, restful contours, the north-facing slopes more wooded and bushy than the drier south-facing ones, which consist of heavily grazed prairie vegetation with brush and small trees only in the bottoms of the coulees. Deltas of the major tributary coulees have dammed the Qu'Appelle River, forming the four Fis hing Lakes - Qu'Appelle (or Pasqua), Echo, Lebret (or Mission), and Katepwa. The town of Fort Qu'Appelle lies on the largest of these deltas, and it was here, in a cabin on the east end of Echo Lake, that my family and I spent two months this spring.

Won over by the enthusiastic recommendations of the Saskatchewan Museum of Natural History and a local amateur birder, Manley Callin, I came to the region on a project sponsored by the National Science Foundation, to study the behaviour and anatomy of grebes. The region was a good one for the purpose: Horned Grebes we re numerous on the potholes above the valley, Pied-bills nested both . on these potholes and in the marshes in the valley, Red-necked Gre bes nested on the large lakes, and the Western Grebe colony in the marsh at the head of Qu'Appelle Lake was a large one. Eared Grebes were found on two sloughs within 30 miles of town. Before the grebes settled on their breeding grounds, there were days when all five species could be seen from our cabin, and I was able to watch many displays from that point.

To one interested in water birds this valley has much to offer. When we arrived in late April there was little open water on the lakes, but ducks were already present in abundance. Almost every day. we saw flocks of Sandhill Cranes, Whistling Swans, Canada Geese, or White Pelicans moving westward up the valley. The strong west winds accompanying the breakup brought a heavy bumper of water weeds to the shore in front of our cabin. In this mass of vegetation, aquatic insects, especially back-swimmers, were abundant and much sought after by birds. Indeed, we could watch a remarkable variety of water birds all day long from our front window. Coots were there in large numbers, Franklin and Bonaparte Gulls in breeding plumage feeding side by side provided interesting comparisons, dabbling ducks and, later, shorebirds added more variety, and a pair of Horned Grebes went so far as to start a nest platform there.

The three miles or more of marshes starting at the west end of Qu'Appelle Lake were especially rich in bird life. Floods several years before had destroyed much of the emergent vegetation, but the reed beds were beginning to make a come-back, e s p e c i a 11 y along the channel of the river which wound through the shallower water of the marsh. Already the reed beds supported colonies of Yellow-headed Blackbirds and Western Grebes. Large numbers of ducks and coots were found on the more open water of the marsh, which also attracted migrating Whistling Swans, White Pelicans, and Canada Geese. Near the upper end of the marsh there were grassy areas where Leconte and Sharp-tailed Sparrows were numerous and mudflats and shallows where shorebirds fed along with ducks. While great numbers of shorebirds were not found, a remarkable variety occurred within 25 miles of Fort $\mathrm{Qu}$ 'Appelle. In all, I found 29 species, including Whimbrel, Long-billed Curley, Hudsonian Godwit, Knot, and Piping Plover, all decidedly uncommon in the region.

We left the Qu'Appelle Valley with many pleasant memories of the scenery, birds, and warm Western hospitality, and with the hope of returning for another spring's field work with Manley Callin. 